\title{
Analisa Dampak Covid-19 terhadap Kinerja Keuangan Perusahaan Pembiayaan di Indonesia
}

\author{
Maria J.F. Esomar \\ Universitas Pattimura Ambon, Maluku \\ Email: dyahesomar@gmail.com
}

\begin{abstract}
The financing industry in Indonesia faces significant challenges due to the Covid-19 pandemic. The amount of financing channeled to the public and debtors ability to pay decreases. The purpose of this study is to analyze the impact of Covid-19 on the financial performance of finance companies by analyzing financial ratios, namely the Financing to Deposit Ratio (FDR), NPF (Non Performing Financing (NPF) Return on Assets (ROA) and Return on Equity (ROE). This study applies a quantitative approach because the data collectedare numbers. The data used are secondary data in the form of finance company statistics published by the Otoritas Jasa Keuangan (OJK), within the period of 9 months before (June 2019 - February 2020) and 9 months after (April 2020 December 2020) the announcement of the first Covid-19 case in Indonesia on March $2^{\text {nd }}, 2020$. The test is conducted using th Paired Sample T-Test. The results of the data processing display that there are differences in the financial performance of finance companies in Indonesia before and after the Covid-19 which can be seen from the results of the Table of Paired Sample T-Test for the ratio of FDR, NPF, ROA, and ROE.
\end{abstract}

Keywords: Financial performance, FDR, NPF, ROA, ROE.

\begin{abstract}
Industri pembiayaan di Indonesia menghadapi tantangan yang cukup signifikan akibat pandemi Covid-19. Jumlah pembiayaan yang disalurkan kepada masyarakat dan kemampuan membayar debitur semakin menurun. Tujuan penelitian ini adalah untuk menganalisis pengaruh Covid-19 terhadap kinerja keuangan perusahaan pembiayaan dengan menganalisis rasio keuangan yaitu Financing to Deposit Ratio (FDR), NPF (Non Performing Financing (NPF) Return on Assets (ROA) dan Pengembalian Ekuitas (ROE). Penelitian ini menggunakan pendekatan kuantitatif karena data yang dikumpulkan berupa angka. Data yang digunakan adalah data sekunder berupa statistik perusahaan pembiayaan yang diterbitkan oleh Otoritas Jasa Keuangan (OJK), dalam periode 9 bulan sebelum (Juni 2019 - Februari 2020) dan 9 bulan setelah (April 2020 - Desember 2020) pengumuman. kasus Covid-19 pertama di Indonesia pada 2 Maret 2020. Pengujian dilakukan dengan menggunakan Paired Sample T-Test. Hasil pengolahan data menunjukkan bahwa terdapat perbedaan kinerja keuangan perusahaan pembiayaan di Indonesia sebelum dan sesudah Covid-19 yang dapat dilihat dari hasil Tabel Paired Sample T-Test rasio FDR, NPF, ROA, dan ROE.
\end{abstract}

Kata Kunci: Kinerja keuangan, FDR, NPF, ROA, ROE.

\section{Pendahuluan}

Persaingan antar dunia usaha semakin kompetitif dan dinamis. Keberlanjutan perusahaan sangat tergantung pada pengelolaan sumber daya dan kondisi lingkungan dunia usaha. Aktivitas perusahaan pembiayaan atau multifinance di Indonesia diperkenalkan pertama sekali oleh pemerintah pada tahun 1974, dengan diterbitkannya SKB Menteri Keuangan, Menteri Perindustrian dan Menteri Perdagangan tentang perizinan usaha leasing (sewa guna usaha). Industri pembiayaan mengalami peningkatan dan berkembang pesat, sehingga menjadi salah satu alternatif sumber pembiayaan bagi pengembangan dunia usaha dari berbagai skala usaha maupun bagi perorangan.

Mewabahnya Covid 19 turut memberi dampak pada lingkungan bisnis dan sektor industri Indonesia termasuk sektor pembiayaan. Perkembangan sektor pembiaayan mengalami 
perlambatan. Industri pembiayaan diperkirakan hanya tumbuh $1 \%$ akibat pandemi covid 19 . Pada masa pandemi covid 19 tantangan yang dihadapi industri pembiayaan yaitu menjaga arus kas dan meningkatnya rasio Non Performing Financing (NPF).

Pinjaman yang disaulurkan dan laba bersih mengalami penurunan, sebaliknya rasio Non Performing Financing (NPF) meningkat. Penyaluran pinjaman hanya mencapai Rp386,3 triliun menurun dari posisi September 2019 yang mencapai Rp 45.112 triliun. Penurunan penyaluran pembiayaan diakibatkan daya beli masyarakat dan permintaan konsumen yang menurun (Lestari, 2019).

Rasio NPF industri pembiayaan pada akhir Mei tahun 2020 mencapai 4,11\%. Rasio NPF ini menjadi yang tertinggi selama lima tahun terakhir ini. Angka itu menjadi catatan NPF tertinggi selama lima tahun terakhir. Penyaluran pembiyaan kendaraan yang merupakan penyumbangan $60-70 \%$ dari total pembiyaaan industry pembiayaan menurun signifikan dibandingkan periode sebelumnya, sektor kendaraan roda dua September 2020 hanya mampu menyalurkan Rp 69,83 miliar menurun dibandingkan September 2019 sebesar Rp 89.03 triliun (Gunawati and PS, 2021).

Meningkatnya rasio non performing financing (NPF), menurunnya jumlah penyaluran pembiaayan dan laba akan mempengaruhi kinerja keuangan.Kinerja keuangan adalah keputusan yang dibuat secara terus-menerus oleh pihak manajemen perusahaan untuk mencapai suatu tujuan tertentu secara efektif dan efisien (Munawir, 2010). Banyak hal yang menjadi tolak ukur kinerja suatu perusahaan pembiayaan, contohnya kemampuan perusahaan dalam menghasilkan laba (Profitabilitas), kemampuan mengendalikan pinjaman bermasalah (NPF) dan kemampuan menyalurkan dana ke pihak ketiga untuk pembiayaan (FDR).

Profitabilitas yang merupakan kemampuan perusahan dalam memperoleh laba (keuntungan) secara optimal dengan mempergunakan sumber-sumber daya dalam bentuk modal yang dimiliki oleh perusahan dalam suatu periode usaha tertentu, alat untuk mengukur laba (profitabilitas) antara lain Return On Asset (ROA) dan Return On Equitty (ROE). Alat ukur yang digunakan dalam penelitian ini adalah Return On Asset (ROA) dan Return On Equitty (ROE). Rasio ini akan memberikan ukuran yang lebih baik atas profitabilitas atas perusahan karena menunjukan efektifitas manajemen dalam mengelola kegiatan perusahan untuk memperoleh pendapatan (Dewi, 2016).

Kinerja perusahaan pembiaayan merupakan kemampuan perusahaan untuk melakukan kegiatan operasional pembiayaan secara normal dan mampu memenuhi semua kewajibannya dengan baik dengan cara-cara yang sesuai dengan peraturan yang berlaku. Berdasarkan kondisi melambatnya pertumbuhan sektor pembiayaan akibat dari mewabahnya covid 19, maka perlu dilakukan analisis dampak covid 19 terhadap kinerja keuangan perusahaan pembiayaan. Industri pembiayaan berusaha menjaga dan meningkatkan kinerja keuangannya walaupun kredit bermasalah yang tercermin dalam rasio NPL netto cenderung meningkat, laba dan penyaluran pembiayaan dana pihak ketiga (DPK) cenderung menurun.

\section{Tinjauan Literatur}

\subsection{Perusahaan Pembiayaan}

Perusahaan pembiayaan merupakan badan usaha diluar bank atau lembaga keuangan non bank lainnya yang memberikan fasilitas pinjaman kepada nasabah. Mekanisme perusahaan pembiayaan diatur dalam Peraturan Menteri Keuangan Nomor 84/PMK.012/2006 tentang Perusahaan Pembiayaan. Pada lembaga pembiayaan pada saat nasabah mengajukan kredit, 
tidak memberikan dana cair tetapi melalui persetujuan, perusahaan membiayai kredit barang nasabah (Harianto, 2017). Peraturan Otoritas Jasa Keuangan No: 29/POJK.05/2014 Tentang Penyelenggaraan Usaha Perusahaan Pembiayaan, kegiatan usaha Perusahaan Pembiayaan semakin meluas mencakup: (1). Pembiayaan Investasi yang merupakan pembiayaan pengadaan barang-barang modal dan jasa yang untuk aktivitas usaha/investasi yang diberikan kepada debitur dan jangka waktu biasanya lebih dari 2 tahun, (2). Pembiayaan Modal Kerja adalah pembiayaan kebutuhan pengeluaran dalam satu siklus aktivitas bisnis debitur dan jangka waktu kurang lebih 2 tahun. (3). Pembiayaan multi guna merupakan pembiayaan pengadaan barang atau jasa untuk konsumsi dan bukan untuk bisnis. (4) Kegiatan pembiayaan lain berdasarkan persetujuan otoritas Jasa Keuangan (OJK).

\subsection{Kinerja Keuangan}

Pengukuran kinerja atau "performing measurement" (pengukuran kinerja) merupakan kemampuan perusahaan mengelola aktivitas bisnis secara efisien dan efektif selama periode akuntansi. Kinerja keuangan adalah analisis yang dilakukan untuk melihat apakah perusahaan telah menerapkan aturan-aturan pengelolaan keuangan dengan baik dan benar. Kinerja keuangan perusahaan pembiayaan dapat dilihat dan diukur dengan menganalisis laporan keuangan (Faisal, Samben, and Pattisahusiwa 2018). Melalui analisis laporan keuangan dapat mengetahui perkembangan dan kekurangan serta hasil yang sudah dicapai perusahaan. Tujuan pengukuran dan penilaian kerja adalah memotovasi karyawan untuk mencapai tujuan perusahaan. Pengukuran kinerja keuangan dapat digunakan sebagai dasar untuk menilai keberhasilan dan kegagalan perusahaan. Kinerja keuangan merupakan gambaran keuangan perusahaan baik dari sisi penggunaan, pendanaan dan pencapaian perolehan laba.

\subsection{Rasio Keuangan}

Rasio keuangan memiliki hubungan dengan kinerja keuangan perusahaan. Rasio keuangan digunakan untuk mengukur kinerja keuangan perusahaan apakah perusahaan mengalami peningkatan maupun penurunan kinerja keuangannya. Penulis menggunakan rasio dalam kinerja keuangannya. Sehingga alasan penulis menggunakan FDR (Financing to Deposit Ratio), NPF (Non Performing Financing), Return On Asset (ROA) dan Return On Equity (ROE) karena dalam melakukan analisis keuangan untuk perusahaan pembiayaan rasio-rasio ini memiliki arti penting dan merupakan teknik analisa yang menyeluruh.

\section{a) Financing to Deposit Ratio (FDR)}

Rasio Financing to Deposit Ratio (FDR) merupakan ukuran Rasio Likuiditas. Rasio Likuditas mengukur jumlah dana yang ditempatkan dalam bentuk pinjaman/pembiayaan yang berasal dari dana yang dikumpulkan oleh perusahaan. Likuiditas juga mengukur kemampuan perusahaan untuk memenuhi kewajiban yang jatuh tempo dari sumber pendanaan arus kas, dan/atau dari aset likuid berkualitas tinggi yang dapat diagunkan, tanpa mengganggu aktivitas dan kondisi keuangan perusahaan. Rumus FDR

$$
F D R=\frac{\text { Total Kredit }}{\text { Dana pihak ketiga }} \times 100 \%
$$

\section{b) Non Performing Financing (NPF)}

Rasio NPF menunjukkan kegagalan debitur dalam memenuhi kewajiban kepada perusahaan. Rasio ini menggambarkan risiko kredit pada aktivitas perusahaan dalam menyalurkan pinjaman. NPF yang tinggi akan memperbesar piutang yang tidak tertagih, sehingga dapat mempengaruhi penerimaan kas dan laba perusahaan dapat menurun dan berpotensi 
mengalami kerugian (Fauzi, 2018). Semakin tinggi NPF ini, maka semakin buruk kualitas pinjaman perusahaan pembiayaan yang menyebabkan meningkatnya jumlah pinjaman bermasalah. Rumus NPL

$$
N P L=\frac{\text { Kredit bermasalah }}{\text { Total Kredit }} \times 100 \% \text { Type equation here. }
$$

c) Return On Asset (ROA) adalah rasio yang menggambarkan hasil (return) atas jumlah aktiva yang digunakan dalam perusahaan. Return On Asset (ROA) merupakan ukuran efektivitas manajemen mengelola investasinya (Ruspandi and Asma, 2016). ROA jua menunjukkan hasil pengembalian investasi dan produktivitas dari seluruh dana perusahaan, baik yang berasal dari modal sendiri dan modal dari pihak luar perusahaan. ROA yang rendah (kecil) menghasilkan kinerja yang kurang baik, demikian pula sebaliknya.

$$
R O A=\frac{\text { Laba Sebelum Pajak }}{\text { Rata }- \text { Rata total aset }} \times 100 \%
$$

d) Return On Equity (ROE) merupakan rasio yang menunjukkan kemampuan perusahaan mengelola modal sendiri (net worth) secara efektif dan efisien, mengukur tingkat keuntungan yang diperoleh dari investasi yang dilakukan pemilik modal sendiri atau pemegang saham perusahaan (Ruspandi and Asma, 2016).

$$
R O E=\frac{\text { Laba bersih setelah Pajak }}{\text { Total Ekuitas }} \times 100 \%
$$

\subsection{Hipotesis Penelitian}

"Terdapat perbedaan kinerja keuangan (Financing to Deposit Ratio, Non Performing Financing, Return on assets, Return on equity, Current Ratio,) sebelum dan sesudah covid 19."

\section{Metode Penelitian}

\subsection{Jenis Penelitian}

Jenis penelitian yang digunakan adalah penelitian pendekatan kuantitatif karena data yang digunaan berbentuk angka-angka. Data yang digunakan dalam penelitian ini adalah data sekunder yaitu data Statistik Perusahaan pembiayaan yang dipublish Otoritas Jasa Keuangan (OJK). Data yang diambil adalah 9 Bulan (Juni 2019 - Februari 2020) sebelum dan 9 Bulan (April 2020 - Desember 2020) setelah pengumuman kasus pertama Covid-19 tgl 2 Maret 2020.

\subsection{Teknik Analisis Data}

Penelitian inimenggunakan paired sample t-test. Paired sample t-test adalah salah satu metode pengujian yang digunakan untuk mengkaji keefektifan perlakuan, ditandai adanya perbedaan rata-rata sebelum dan rata-rata sesudah diberikan perlakuan (Ilhami and Thamrin, 2021). Pengujian ini digunakan untuk mengukur seberapa besar perbedaan kinerja keuangan perusahaan pembiayaan di Indonesia, sebelum diumumkan kasus Covid-19 pertama kali di Indonesia dan sesudah pengumuman. Variabel-variabel pada penelitian ini, yang digunakan adalah:

1) Data sebelum kasus Covid-19 di umumkan secara nasional di Indonesia untuk petama kali. Data sebelum pegumuman nasional kasus Covid-19 di Indonesia untuk pertama kali 
ini meliputi data laporan keuangan berupa Financing to Deposit Ratio (FDR), NPF (Non Performing Financing (NPF) Return on Assets (ROA) dan Return on Equity (ROE). Pada penelitian ini, data yang diambil sebelum kasus pertama virus corona sebanyak 9 .

2) Data sesudah kasus Covid-19 di umumkan secara nasional di Indonesia untuk petama kali. Data sesudah pegumuman nasional kasus Covid-19 di Indonesia untuk pertama kali ini meliputi data laporan keuangan berupa Financing to Deposit Ratio (FDR), NPF (Non Performing Financing (NPF) Return on Assets (ROA) dan Return on Equity (ROE). Pada penelitian ini, data yang diambil sesudah kasus pertama virus corona sebanyak 9.

3) Pengumuman kasus Covid-19 pertama kali di Indonesia untuk pertama kali terhitung tanggal 2 Maret 2020.

\subsection{Pengujian Hipotesis}

Pengujian statistik dilakukan dengan menguji kinerja keuangan sebelum dan sesudah pengumuman pandemi covid 19 pertama kali di Indonesia, Tahap-tahap pengujian menggunakan pengujian parsial untuk variabel penelitian dengan Paired Samples T Test. Tingkat signifikansi atau nilai alfa pada penelitian ini ditetapkan adalah sebesar 0,05 atau 5\%. Pengujian hipotesis ini menggunakan uji Paired Samples $T$ Test karena model uji beda tersebut populer digunakan untuk model penelitian pre-post atau sebelum-sesudah. Uji beda digunakan untuk mengevaluasi perlakuan (treatment) tertentu pada satu sampel yang sama pada dua periode pengamatan yang berbeda yaitu sebelum dan sesudah adanya treatment. Treatment tertentu pada penelitian ini adalah peristiwa pengumuman pertama kali pandemi covid 19 di Indonesia. Jika treatment tersebut tidak berpengaruh pada subjek, maka nilai ratarata pengukurannya adalah sama dengan atau dianggap nol dan hipotesis nol (Ho)nya tidak didukung, yang berarti hipotesis alternatifnya didukung. Paired Samples T Test atau uji T sampel berpasangan merupakan uji parametrik yang digunakan untuk menguji hipotesis sama atau tidak berbeda (Ho) di antara dua variabel. Data berasal dari dua pengukuran atau dua periode pengamatan yang berbeda yang diambil dari subjek yang dipasangkan.

\section{Hasil dan Pembahasan}

\subsection{Hasil Penelitian}

Uji Normalitas

Tabel 1. Tabel Hasil Uji Normalitas

Tests of Normality

\begin{tabular}{lr|r|r|r|r|r} 
& \multicolumn{2}{c}{ Kolmogorov-Smirnov $^{\text {a }}$} & \multicolumn{4}{c}{ Shapiro-Wilk } \\
& Statistic & df & \multicolumn{1}{c|}{ Sig. } & Statistic & df & \multicolumn{1}{c}{ Sig. } \\
\hline FARPre & .243 & 9 & .134 & .875 & 9 & .139 \\
\hline FARPost & .186 & 9 & $.200^{*}$ & .911 & 9 & .320 \\
\hline NPFPre & .183 & 9 & $.200^{*}$ & .942 & 9 & .606 \\
\hline NPFPost & .113 & 9 & $.200^{*}$ & .969 & 9 & .890 \\
\hline
\end{tabular}




\begin{tabular}{lllllllll}
\hline ROAPre & .224 & 9 & $.200^{*}$ & .855 & 9 & .084 \\
\hline ROAPost & .167 & 9 & $.200^{*}$ & .905 & 9 & .282 \\
\hline ROEPre & .193 & 9 & $.200^{*}$ & .904 & 9 & .276 \\
\hline ROEPost & .180 & 9 & $.200^{*}$ & .904 & 9 & .276 \\
\hline
\end{tabular}

*. This is a lower bound of the true significance.

a. Lilliefors Significance Correction

Uji normalitas memiliki tujuan apakah suatu data memiliki distirbusi normal atau tidak. Jumlah n kurang dari 30 sehingga uji normalitas menggunakan uji Shapiro Wilk, bila tingkat signifikansi $>0.05 \%$. Hasil Output SPSS menunjukkan hasilnya diatas $0.05 \%$ sehingga data terdistribusi normal.

Paired Sampel Statistik

Tabel 2. Tabel Hasil Uji Paired Sampel Statistik

\section{Paired Samples Statistics}

\begin{tabular}{|c|c|c|c|c|c|}
\hline & & Mean & $\mathrm{N}$ & Std. Deviation & $\begin{array}{l}\text { Std. Error } \\
\text { Mean }\end{array}$ \\
\hline \multirow[t]{2}{*}{ Pair 1} & FARPre & 87.3411 & 9 & .11005 & .03668 \\
\hline & FARPost & 82.0411 & 9 & .85362 & .28454 \\
\hline \multirow[t]{2}{*}{ Pair 2} & NPFPre & 2.5689 & 9 & .20423 & .06808 \\
\hline & NPFPost & 4.6178 & 9 & .71834 & .23945 \\
\hline \multirow[t]{2}{*}{ Pair 3} & ROAPre & 4.7722 & 9 & .05380 & .01793 \\
\hline & ROAPost & 1.7956 & 9 & .08705 & .02902 \\
\hline \multirow[t]{2}{*}{ Pair 4} & ROEPre & 14.8322 & 9 & .10390 & .03463 \\
\hline & ROEPost & 4.7378 & 9 & .40252 & .13417 \\
\hline
\end{tabular}

Diketahui nilai mean X1 pre test sebesar 87.34 dan ini lebih besar dari hasil post test 82.04 , dan ini menandakan perbedaaan. Mean X2 pre test 2.56 , lebih kecil dari mean x2 post test 4.6. Mean X3 pre test 4.7 lebih besar dari mean post test $\mathrm{x} 31.79$ dan mean X4 pre test 14.8 lebih besar dari mean $\mathrm{x} 4$ post test 4.7 sehingga menunjukkan ada perbedaan kinerja keuangan sebelum dan sesudah terjadinya covid 19. 
Hasil Pengujian Hipotesis

Tabel 3. Tabel Hasil Pengujian Hipotesis

\section{Paired Samples Test}

Paired Differences

\begin{tabular}{|c|c|c|c|c|c|c|c|}
\hline \multirow{2}{*}{ Mean } & \multirow{2}{*}{$\begin{array}{c}\text { Std. } \\
\text { Deviation }\end{array}$} & \multirow{2}{*}{$\begin{array}{c}\text { Std. Error } \\
\text { Mean }\end{array}$} & \multicolumn{2}{|c|}{$\begin{array}{l}95 \% \text { Confidence } \\
\text { Interval of the } \\
\text { Difference }\end{array}$} & \multirow[b]{2}{*}{$\mathrm{t}$} & \multirow[b]{2}{*}{$\mathrm{df}$} & \multirow{2}{*}{$\begin{array}{l}\text { Sig. (2- } \\
\text { tailed) }\end{array}$} \\
\hline & & & Lower & Upper & & & \\
\hline
\end{tabular}

\begin{tabular}{rr|r|r|r|r|r|r|r|r}
\hline $\begin{array}{r}\text { Pair 1 FARPre - } \\
\text { FARPost }\end{array}$ & 5.30000 & .82140 & .27380 & 4.66862 & 5.93138 & 19.357 & 8 & .000 \\
\hline $\begin{array}{r}\text { Pair 2 NPFPre - } \\
\text { NPFPost }\end{array}$ & 2.04889 & .87014 & .29005 & -2.71773 & -1.38004 & -7.064 & 8 & .000 \\
\hline $\begin{array}{r}\text { Pair 3 ROAPre - } \\
\text { ROAPost }\end{array}$ & 2.97667 & .12124 & .04041 & 2.88347 & 3.06986 & 73.653 & 8 & .000 \\
\hline $\begin{array}{r}\text { Pair 4 ROEPre - } \\
\text { ROEPost }\end{array}$ & 10.0944 & .47914 & .15971 & 9.72614 & 10.46275 & 63.203 & 8 & .000 \\
\hline
\end{tabular}

\subsection{Pembahasan.}

Berdasarkan Tabel Paired sampel $\mathrm{t}$ test . diatas yang adalah hasil olahan data yang menggunakan uji beda dua rata-rata (paired sample t-test) dengan signifikansi 0,05 menghasilkan analisis yang menunjukan bahwa sebelum dan sesudah terjadinya covid 19 terdapat perbedaaan kinerja keuangan. Rasio Financing to Deposit Ratio (FDR) nilai t hitung $=19.357>\mathrm{t}$ table $=2,306$ dengan signifikansi sebesar 0,000 dibawah nilai $\alpha$ yaitu sebesar 0,05 sehingga hipotesis diterima. Artinya bahwa terjadi perbedaan yang signifikan antara Financing to Deposit Ratio (FDR) sebelum dan sesudah terjadinya covid 19. Terjadinya covid 19 mengakibatkan adanya penurunan penyaluran pembiayaan. Variabel Non Performing Financing (NPF) menunjukan terdapat perbedaan kinerja keuangan. Rasio NPF lebih kecil sebelum covid 19 dan meningkat setelah terjadinya covid 19 namun masih posisi yang ideal karena kurang dari 5\%. Rekstrukturisasi debitur yang terkena dampak covid 19 dilakukan sebagai salah satu kebijakan relaksasi kredit perusahaan pembiayaan. Untuk rasio Return on Assets (ROA) dan Return on Equity(ROE) dari hasil olah data menunjukkan nilai signifikansi sebesar 0.000 lebih kecil dari 0.05 dan artinya ada perbedaaan kemampuan perusahaan menghasilkan laba dengan aset maupun laba dengan modal sebelum dan sesudah terjadinya covid 19, hal ini megakibatkan rasio profitabilitas yang diukur dengan ROA dan ROE mengalami perubahaan. OJK mecatat terjadi penurunan laba bersih setelah pajak pada industri pembiayaan, laba menurun $59.31 \%$, laba yang diperoleh per 30 september 2020 hanya mencapai Rp7.47 triliun, padahal di periode yang sama sebelum terjadinya pandemi covid 19, industri pembiayaan berhasil memperoleh laba Rp 18.36 triliun.

\section{Kesimpulan}


Dari hasil olah data, menunjukkan adanya perbedaan kinerja keuangan perusahaan pembiayaan di Indonesia yang dilihat dari hasil tabel UjiBeda (Uji Paired Sample T-Test) rasio FDR, NPF, ROA dan ROE signifikan menunjukkan adanya perbedaan kinerja keuangan pada industri pembiaayaan sebelum dan sesudah terjadinya pandemi covid 19. Hal ini berarti industri pembiayaan perlu melakukan langkah strategis dan inofatif untuk meningkatkan kinerja keuangan. Perusahaan pembiayaan meningkatkan penerapan manajemen risiko dan melakukan penyaluran pembiayaan untuk masyarakat, menurunkan rasio kredit bermasalah sehingga dapat meningkatkan laba perusahaan.

\section{Daftar Pustaka}

Dewi, Putu Eka Dianita Marvilianti. 2016. "Pengaruh Rasio Likuiditas, Rasio Profitabilitas, Rasio Aktivitas, Rasio Solvabilitas, Dan Rasio Nilai Pasar Terhadap Return Saham.” Jurnal Ilmiah Akuntansi.

Faisal, Ahmad, Rande Samben, and Salmah Pattisahusiwa. 2018. "Analisis Kinerja Keuangan." KINERJA.

Fauzi, Achmad. 2018. "Kredit Macet, NPL Dan Pengaruhnya Terhadap Kinerja Perusahaan Pada Perusahaan Pembiayaan." Jumabis: Jurnal Manajemen dan Bisnis 2(1).

Gunawati, Anne, and Agus Prihartono PS. 2021. "HUBUNGAN RESTRUKTURISASI PERJANJIAN PEMBIAYAAN KONSUMEN SEPEDA MOTOR DENGAN POJK NO. 11/POJK. 03/2020 TENTANG STIMULUS PEREKONOMIAN NASIONAL." Legal Standing: Jurnal Ilmu Hukum 5(1): 104-12.

Harianto, Syawal. 2017. "Rasio Keuangan Dan Pengaruhnya Terhadap Profitabilitas Pada Bank Pembiayaan Rakyat Syariah.” ESENSI.

Ilhami, and Husni Thamrin. 2021. "Analisis Dampak Covid 19 Terhadap Kinerja Keuangan Perbankan Syariah Di Indonesia." Jurnal Tabarru': Islamic Banking and Finance 4(1): $37-45$.

Lestari, Novi Puji. 2019. "Menata Perekonomian Indonsia." Arsip Publikasi Ilmiah Biro Administrasi Akademik.

Munawir. 2010. Jakarta: Salemba Empat Analisa Laporan Keuangan Edisi 4.

Ruspandi, Hasan, and Rusdayanti Asma. 2016. "Faktor-Faktor Yang Mempengaruhi Profitabilitas Perusahaan Pembiayaan Di Indonesia." JWM (Jurnal Wawasan Manajemen) 2(1): 97-118. 